Published as: Kate Macdonald, "The Meaning and Purposes of Transnational Accountability", Australian Journal of Public Administration, 73.4 (2014), pp.426-436

\title{
The meaning and purposes of (transnational) accountability
}

\section{Introduction}

It is now commonplace for the language of accountability to be invoked outside of the national democratic context - in both public and scholarly debates about the operation of transnational power and governance. In practical political discourse, calls for 'strengthened accountability' have played a central part in activist demands to reform prominent global governance institutions such as the World Bank, or to create new systems of transnational governance to control the power of large transnational companies. Meanwhile, scholars examining diverse fields of global governance ranging from the operations of humanitarian Non-Governmental Organisations (NGOs), to the programs of United Nations agencies, multi-stakeholder processes of global environmental governance or the negotiation of new international trade rules within the World Trade Organisation, have directed increasing analytical scrutiny to processes through which those responsible for the conduct and consequences of such diverse governance activities can be held to account by their multiple stakeholders (Kahler 2004; Scholte 2004; Zurn 2004; Clapp 2005; Held and Koenig-Archibugi 2005; Chesterman 2008; Newell 2008). Clearly, any examination of the 'state of the art' of accountability must pay serious attention to developments in the transnational governance domain.

Much of the burgeoning scholarship addressing transnational accountability can be found in either the field of international relations_-broadly defined to encompass inter-disciplinary studies of globalization and global governance-or sometimes in specialist parts of the public administration literature focused on European governance. With a few notable exceptions (eg.(Koenig-Archibugi 2010)), there is often little direct dialogue and engagement between analyses of accountability approached through a global governance lens, and the huge body of scholarly work addressing concepts and practices of accountability in the context of national public administration and governance. The much-noted elasticity of this “complex and chameleon like term” (Mulgan 2000, p.555) enables discourses of accountability to travel easily across these differing fields of scholarship and practice. Nonetheless, the apparent disconnect between analyses of accountability at national and transnational scales raises the question—highlighted in the introduction to this special issue-as to whether the extension of 'accountability talk' to the transnational domain overstretches the concept of accountability, thereby blurring or distorting our analysis of concepts, practices and purposes of accountability. 
As (Koenig-Archibugi 2010, p.1142) cautions, “[f]ew fallacies are frowned upon by International Relations scholars more than those related to naïve applications of the so-called 'domestic analogy'”. Although both the language and certain institutional practices associated with transnational accountability appear familiar from the national context, any assumption that 'accountability' takes an analogous form between the national, supranational and transnational governance levels must therefore be subjected to serious analytical scrutiny. With this caution in view, the below discussion presents a brief anatomy of concepts and practices of transnational accountability, and reflects on key analogies and disanalogies between national and transnational governance domains. Discussion is organised around a set of questions on which many attempts to develop typologies of different accountability models or regimes have focused: accountability 'for what', 'to whom', 'through what means' and 'for what purpose' (Mulgan 2003; Mashaw 2005).

The paper suggests that although the same core meaning of accountability is equally relevant at transnational as at national scale, there are some notable differences in how questions about accountability 'for what', 'to whom' and 'through what means' are answered in a transnational governance setting. Challenges of defining the legitimate parties to and subject matter of transnational accountability relationships are shown to be particularly prone to ambiguity and contestation. Moreover, repertoires of accountability mechanisms vary in some significant ways at transnational compared to national levels, despite widespread reliance on familiar institutional processes. Such differing patterns and tendencies are by no means coincidental; rather, they can be understood as reflecting some of the distinctive material and ideational features of a transnational polity, entailing significant plurality of actors and relationships; contestation of the norms constituting roles and responsibilities of key actors; and configurations of public power and authority that are highly decentred, asymmetrical, and dynamic. ${ }^{1}$

Yet far from this distinctive character of a transnational polity implying that the concept of accountability is 'overstretched' in its transnational application, the paper finds that focusing on distinctive as well as familiar features of transnational accountability can in fact enhance our understanding of the underlying purpose and significance of accountability within public governance processes at any scale. In particular, analysing accountability in the highly dynamic and contested transnational governance environment focuses our attention on the purpose and function of accountability not only as a means of legitimizing and stabilizing public governance processes, but also as a normative and institutional foundation for political contestation and institutional change.

\footnotetext{
${ }^{1}$ Although a transnational polity exhibits particularly striking features of plurality, contestation and decentred power, there are important parallels in these respects with contemporary national governance environments (Rosenau 1990; Papadopoulos 2003; Rosenau 2005; Harrison 2006; Duit and Galaz 2008; Geyer and Rihani 2010).
} 


\section{Meanings of accountability}

Before beginning to dissect specific transnational accountability practices in our search for analogies and disanalogies, we must first establish whether analysts of national and transnational ‘accountability' are even talking about the same thing. We must clarify in other words whether different concepts of accountability are being deployed for analysis of relationships within a national governance system, compared with "relationships among actors who are primarily based in different state jurisdictions, or involving actors transcending state jurisdictions” (Koenig-Archibugi 2010, p.1142).

Contrary to such worries about conceptual disanalogy, reviews of accountability in both international relations and public administration literatures reveal significant convergence on an agreed conceptual core (Koenig-Archibugi 2010; Goodhart 2014 ); (Mulgan 2000; Bovens 2007). For example, based on a systematic comparison of concepts of accountability articulated in literatures on public

administration, democratization studies and international relations, (Koenig-Archibugi 2010, p.1143) concluded that the core meaning of accountability "is not dependent on assumptions about the political context defined simply in terms of the presence or absence of statehood.”

On this convergent view, accountability is understood as a moral or institutional relation in which one agent (or group of agents) is accorded entitlements to question, direct, sanction or constrain the actions of another-particularly where these actions involve the exercise of public power or authority within a governance system. Importantly, accountability relations on this view are tied closely to core constitutive norms underpinning governance arrangements more broadly: embodying principles about who can rightfully demand what reasons and actions from which other actors, on what grounds, and what recourse accountability-holders are both entitled and empowered to call upon if such responses are not forthcoming.

At a purely conceptual level then — that is at a relatively high level of abstraction from details of particular norms, actors and institutions - there appears to be little difficulty in translating analyses of accountability between domestic and transnational contexts. It is at a more operational level of analysis, where differences in how norms and power relations underpinning the relationships between specific actors are constituted, that we begin to find relevant patterns of variation in accountability practices, reflecting the distinct normative and material features of a transnational polity.

\section{Accountability in relation to what?}

We first search for distinctive characteristics of the subject matter of transnational accountabilityexamining the question, in other words, of 'accountability in relation to what'? We can understand this both as a question of what actions or outcomes decision makers are liable to be called to account 
for, as well as by what standards the putatively accountable behaviour is to be judged (Mashaw 2005, p.17).

To the extent that we remain at a relatively high level of abstraction, the shift to a transnational scale need not alter our answer to this question. We can observe in general terms that actors within a public governance system are typically accountable for their performance of a designated role and/or adherence to designated behavioural rules. Defining the subject matter of accountability in this way does not tell us anything about the substantive norms sitting behind such roles, responsibilities or rules. In this more abstract sense, accountability functions as a kind of shell or umbrella term—what (Mashaw 2005, p.15) has called a "placeholder” concept. In other words, although the core concept of accountability makes reference to an underlying normative framework that defines the terms on which certain behaviour can be assessed, the concept of accountability in itself tells us nothing further about the content of such obligations.

What then when we consider in more substantive terms what roles, responsibilities and behavioural rules constitute accountability relationships within a transnational governance context? Still, little can be said to generalise about the specific actions or outcomes to which transnational accountability relationships pertain: these will be as diverse as are the policy objectives promoted by transnational governance systems and the mixes of actors and delivery mechanisms through which these are pursued. Relevant evaluative standards will be similarly varied in their content, as well as in the degree of autonomy they provide to the subjects of accountability relationships: while some standards require compliance with highly prescriptive behavioural standards, in other cases performance is assessed in a more holistic and discretionary manner. All of this is equally true for transnational as for national accountability relationships.

Where the subject matter of accountability relationships does sometimes begin to differ in meaningful ways from the national level is in the degree of ambiguity and contestation that characterises the definition of such relationships. While all governance arrangements display ambiguities and disagreements with regard to what claims that a particular governance actor ought to be 'more accountable' to some other entity are understood to mean, such disagreement is often particularly intense in the transnational arena, reflecting quite foundational normative contestation regarding the roles and responsibilities of key governance actors and institutions.

For example, ambiguity and contestation of this kind has been pervasive within processes of transnational corporate accountability, whereby 'corporate accountability’ campaigners have explicitly rejected claims that regulation of labour, social and environmental standards associated with corporate activity is the exclusive responsibility of governments-demanding instead that companies be held directly accountable for their social and environmental impacts. As many targeted companies have resisted such claims, the resultant dynamics of contested accountability have been underpinned 
by fundamental disagreements and associated uncertainty regarding the content and scope of what companies can properly be held responsible and accountable for (Macdonald 2007). Although disagreement and ambiguity concerning appropriate divisions of responsibility are part of the politics of accountability in any context, such tensions are often intensified at the transnational level. In part this reflects intensified cultural and political pluralism at global scale (Keohane 2003), and in part the emergent character of global governance, which is associated with both heightened uncertainty and intensified processes of political contestation surrounding evolving governance arrangements (Buchanan and Keohane 2006).

\section{Accountability to whom?}

Such ambiguity and contestation —or "contentiousness"-is not restricted to questions about the subject matter of transnational accountability relations. Contentiousness of transnational accountability relations is often striking also in relation to problems of 'stakeholder identification' (Koenig-Archibugi 2010, p.1154). Debates about ‘to whom' accountability ought to be established in transnational governance have frequently been framed with reference to lamentation about the proliferation of 'accountability deficits' in this context. However, as analysts of transnational accountability have sometimes observed (Grant and Keohane 2005; Koenig-Archibugi 2010; Goodhart 2014 ), the problem is not simply 'too little’ accountability at the transnational level. In many respects, perceived accountability 'deficits' reflect not so much an absence of accountability, but rather normative debate about who power wielders ought to be held accountable to. As (Krisch and Kingsbury 2006, p.4) observe, "there may be robust accountability but to the wrong people or on the wrong topics".

Debates surrounding the accountability of the World Bank illustrate such dynamics clearly. As a major inter-governmental body, the Bank possesses some relatively settled relationships of accountability that track the major 'principal-agent' relationships around which its development finance activities have traditionally been organised—in particular the accountability of World Bank staff to the governments of member states (Woods 2001; Grant and Keohane 2005). Much transnational political debate concerning the legitimacy of the World Bank's activities and influence has focused on the perceived neglect within such accountability relationships of accountability to communities affected directly by Bank funded projects and programs. In response to periods of intense civil society pressure over the past two to three decades, the Bank has increasingly acknowledged the need for their decisions to be answerable to an expanding array of 'stakeholders' outside their own organisation, through increased transparency, strengthened dialogue with external stakeholders, and provision of access to grievance procedures for project-affected people (Fox and Brown 1998; O'Brien, Goetz et al. 2000; Scholte 2004). Yet the way in which Bank staff are to 
balance the competing array of accountabilities that results remains the subject of significant ambiguity and debate.

In the presence of such contestation, what results is often a contested plurality of stakeholders and mechanisms, with relations to one another that are not clearly defined (Benner, Reinicke et al. 2004; Krisch 2006; Ebrahim and Weisband 2007). (Krisch 2006, p.10) for example has characterised the global accountability space as a contest of different constituencies over who should be entitled to control regulatory and policy outcomes, resulting in "a pluralism of procedures and regimes that seek to establish accountability through mutual challenge”.

Multiple, competing accountability claims are of course by no means unique to transnational governance settings. Notorious problems of competing accountability claims are also associated with non-hierarchical governance arrangements operating at national and sub-national levels (Kersbergen and Waarden 2004; Papadopoulos 2007). Nevertheless, the pluralism observed at the transnational level is distinguished not merely as a matter of degree. At the national level, competing claims exist within an overarching constitutional framework, to which opposing claims are ultimately subordinated. At the transnational level, such centralised, constitutional frameworks for defining and resolving competing claims are absent (Krisch 2006).

\section{Accountability through what means?}

Significant plurality of accountability arrangements is also evident as we turn our attention to the question of what institutional means are deployed as a basis for transnational accountability. In many respects, the overall repertoire of accountability mechanisms at the transnational level is familiar to observers of accountability in a national public administration context. There is a relatively high degree of agreement across public administration and international relations literatures on appropriate classification of different forms or types of accountability mechanisms, underlining the similarities at least in the relevant institutional toolboxes (Koenig-Archibugi 2010). For example, (Romzek and Dubnick 1987) identify bureaucratic, legal, professional and political forms of accountability in the national public administration context, while (Grant and Keohane 2005) distinguish hierarchical, supervisory, fiscal, legal, market, peer and public reputational mechanisms, in their influential analysis of accountability in global governance. ${ }^{2}$

Although legal, political and administrative accountability in particular take rather distinctive forms in the transnational domain, examples of all these varieties of accountability abound. For example, (Kingsbury, Krisch et al. 2004) and others within a burgeoning scholarship on so-called 'global

\footnotetext{
${ }^{2}$ Both nationally and transnationally focused accountability scholars continue to debate such typologies, with particular scepticism being expressed regarding the potential for market mechanisms to function as instruments of public accountability (Mulgan 2000; Bovens 2010). Nonetheless, use of such typologies persists across both clusters of the accountability scholarship.
} 
administrative law' have documented the widespread use of accountability procedures that parallel administrative accountability at national levels, such as the use of transparency, notice and comment procedures in rule making, and avenues of judicial and administrative review. Such procedures are present in an array of transnational policy areas such as global banking regulation, Security Council sanctions administration, international administration of refugees or the domestic regulation of transboundary environmental issues (Krisch and Kingsbury 2006; Chesterman 2008). Likewise, professional and peer review occurs through a range of international forums, such as state to state peer review within the OECD, or involving broader policy communities that also encompass non state actors (such as the work of World Health Organisation committees). Transnational market accountability can occur through the mobilization of investors or consumers to hold companies to account for their social and environment practices, or via bond and equity holders calling to account national governments or multilateral agencies whose activities they help to finance (Koenig-Archibugi 2010).

Although much of the transnational accountability landscape thus appears rather familiar, in institutional terms, there are some significant differences in patterns of usage of different kinds of accountability arrangements at the transnational level. One widely noted difference relates to the disproportionate reliance on transnational accountability mechanisms that operate through 'soft' law or non-state mechanisms - a difference that is often linked to the highly decentred political authority structure prevailing in the transnational domain. These may take the form of market-based accountability, such as in the examples just mentioned, horizontal accountability through transgovernmental networks (Slaughter 2004), or scrutiny and informal sanction associated with transnational civil society oversight of global governance processes (Scholte 2004; Goodhart 2014 ). Even where accountability mechanisms have the backing of states, governments are often unwilling to empower external entities to impose sanctions or implement other kinds of remedies in ways that involve significant autonomy from member states, thus significantly limiting the capacity of transnational mechanisms to offer effective sanction or redress in response to accountability claims (Park 2014).

Another notable feature of many accountability mechanisms used in transnational governance is their significant reliance on third party intermediaries. A number of analyses have recently emerged highlighting a distinction between direct and intermediated (proxy or surrogate) forms of accountability (Rubenstein 2007; Koenig-Archibugi and Macdonald 2013; Goodhart 2014). Within proxy or surrogate accountability arrangements, intermediaries play important roles in shaping or endorsing standards, receiving information about compliance, and sanctioning power wielders, nominally 'on behalf' of the accountability holders. An important underlying driver of this trend at the transnational level is the presence of significant power differentials between decision makers and 
those affected, as well as the greater physical and social distance between relevant actors, and the absence of formal institutions mediating these relations (Koenig-Archibugi 2010; Goodhart 2014).

\section{The purposes of (transnational) accountability}

Despite significant parallels between accountability practice at national and transnational levels, we have therefore seen that distinctive dynamics of pluralism and contestation characterising the transnational polity are also associated with some notable differences. As we will now explore, these distinctive dynamics can draw our attention to some fundamental yet often overlooked purposes of accountability—of importance to national as well as transnational political contexts.

Much analysis of the purposes of accountability has focused on 'purposes' in the sense of the specific, strategic purposes that political actors are trying to advance when they consciously engage in accountability practices. In this regard, analyses of the purposes of accountability seem to translate rather well from national to transnational arenas. Bovens' typology of accountability purposes is particularly widely cited in this regard. On this conception, "Accountability is important to provide a democratic means to monitor and control government conduct, for preventing the development of concentrations of power, and to enhance the learning capacity and effectiveness of public administration” (Bovens 2007, p.462). There is no shortage of examples of such accountability purposes from the transnational context, including the role of international law in sanctioning or constraining state power (through webs of courts, treaties, sanctions, tribunals and legal doctrines), processes of learning attained through systems of monitoring, evaluation and results-based management models for international development programs, or processes of grievance and stakeholder participation designed to enable responsiveness to stakeholders on the part of multilateral development agencies such as the World Bank, discussed earlier (Koenig-Archibugi 2010; Goodhart 2014 ).

In addition to considering such specific, strategic purposes of accountability, analysts of transnational accountability have often highlighted the deeper systemic purposes that robust accountability arrangements can support within a governance system as a whole. The most fundamental systemic purpose of accountability is frequently identified as that of legitimizing governance arrangements. (Koenig-Archibugi 2010, p.1146) for example suggests that "[a]ccountability is demanded, supplied and studied mainly because of the expectation that it will contribute to establishing, maintaining or enhancing legitimacy.” (Weisband and Ebrahim 2007, p.9-10) likewise point to the widespread view that "accountability provides a sense of stability in organizational relations by maintaining the commitments of members and clients”. In this sense, they observe, a central purpose of accountability is "creating stability and assuring public confidence". 
The contributions accountability can make to both specific, strategic objectives, and to the legitimation and stability of the governance system as a whole, are potentially significant. Yet accountability systems are not the only or even necessarily the best way of achieving these goals—as (Mulgan 2000)'s analysis reminds us. What then can we say about the more distinctive contribution of accountability to purposes of these kinds?

One feature of accountability practice that is particularly salient in this regard is its character as a political process based on active questioning. Because a functional accountability process depends centrally on the presence of active scrutiny and critical exchange between the parties to the accountability relationship, accountability processes have a distinctive tendency to foster active, engaged and critical practices of political agency. This importantly underpins the capacity of accountability to support processes of legitimation within governance: by encouraging and enabling political acts that challenge deviations from accepted norms or agreed outcomes, accountability processes can provide some institutionalised protection for established governance norms-whether these relate to goals of effectiveness, responsiveness, checking the abuse of power, or something else.

However, although the active political agency on which accountability processes depend might usually be oriented towards a systemic function of legitimation, a pervasive culture of critical engagement amongst (at least certain) political agents can also generate a distinctive potential for accountability to be deployed to question and challenge routine practice or established patterns of behaviour. Indeed, accountability claims can sometimes be deployed as a means of challenging quite fundamental norms and relationships within a governance system. In this sense, accountability processes can offer a vehicle not only for legitimation of governance arrangements, but also for delegitimation; not just for overarching purposes of system maintenance and stability, but as an entry point and a vehicle for contesting and transforming core constitutive features of the governance system. In this transformative mode, accountability practices can "signal the denial of consent, not just to particular acts of power but to the fundamental structure of institutions through which power is distributed and legitimized” (Macdonald 2007, p.260).

The potential of accountability discourses and institutions to be appropriated as vehicles of deeper political contests reflects not only the dynamic of critical political agency that lies at the heart of accountability processes, but also the linkage of accountability relationships to foundational constitutive norms regarding who can rightfully demand what from whom within a governance system. Contests over defining the terms of accountability norms and institutions can therefore provide a distinctively influential strategy for challenging both norms and power relations within a governance system. 


\section{Transformative accountability politics}

The potential significance of this transformative function of accountability practice is often downplayed or marginalised within mainstream governance literature. Nevertheless, it is difficult to overlook when interpreting some of the most prominent examples of accountability politics at the transnational level.

One clear example of such dynamics is the accountability politics surrounding the governance of World Bank project finance, and its impacts on developing country communities—referred to above. Increasing recognition of communities affected by World Bank projects as legitimate bearers of accountability claims emerged as a product of extensive political mobilization in the 1980s and 90s by civil society groups in key lender countries (particularly the United States), often in coordination with grassroots organisations from project affected communities. Recognition of such norms has been given progressive institutional expression through creation of accountability mechanisms such as the World Bank Inspection Panel, which enable people affected by Bank funded projects to register grievances and initiative investigations into whether the Bank has adhered to its own social and environmental policies in relation to a given project (Fox and Brown 1998; Scholte 2004, p.212).

Many examples of a similar nature can be invoked in this regard. The progressive contestation and reconstruction of transnational norms governing corporate accountability, also referred to above, has followed a similar dynamic (Macdonald 2007). In the field of global environmental politics also, "accountability is at the heart of many of the key debates about responsibility for action on climate change, even if not often named in those terms” (Mason 2005; Newell 2008, p.122). Similarly, (Keck and Sikkink 1998)'s influential analysis of the impact of transnational advocacy networks campaigning on issues of human rights, environmental protection and tackling violence against women attributes a central role to "accountability politics" as a means of effectively ratcheting up processes of normative change by using accountability claims to expose increasing distance between shifting discourse and established practice.

In all of these examples, the capacity of a critical politics of accountability to leverage change in a governance system is centrally tied to the meaning and purposes of accountability that we have explored above. Accountability relationships lay out normative standards regarding who has the right to seek information, justification and responsiveness from whom, on what range of issues, and they put in place institutional systems that empower relevant stakeholders to assert such claims against those they hold to account. Transformative accountability practices attempt to reconstruct accountability relationships in both these normative and institutional dimensions-challenging norms of responsibility, and also attempting to reconstruct the material relations of power that lie at the heart of any accountability system. 
Correspondingly, transformative accountability claims tend to emerge in response to some combination of shifting relations of material power and interconnection, and shifting norms amongst key actors. As material relationships of power and affectedness evolve as a result of structural social change, such accountability often develops through a process that 'tracks' shifting patterns of power and affectedness (Macdonald and Macdonald 2010) - following a "reactive” political dynamic (Zurn 2004, p.285; Mason 2005, p.4). Such material changes are not sufficient in themselves, however. Shifting accountability arrangements typically also require changing social expectations in key constituencies regarding the responsibilities of decision makers to their stakeholders, together with social mobilization demanding corresponding institutional change.

Recognising the way in which accountability is socially constructed, contested and renegotiated through such dynamic political processes underscores the character of accountability as "a social phenomenon shaped by and reflective of alternating alignments of politics, cultures, social norms and institutional expectations” (Weisband and Ebrahim 2007, p.3). Across a range of transnational governance domains, normative contestation and change is being expressed in the language of accountability, and conflicts between different political relationships and arenas are played out in the form of conflicting and competing processes of accountability. Through such processes, accountability discourses and practices are actively constructing, not merely consolidating and protecting, relationships of responsibility and mutual obligation.

In the study of transnational politics, such potential of "accountability politics" to underpin transgressive modes of political organising is widely recognised. In studies of national and subnational political processes, by way of contrast, analysis of what (McAdam, Tarrow et al. 2001) have labelled 'transgressive' politics has tended to be dominated by specialised scholars of social movements or 'contentious politics'. Analysis of accountability has tended to remain primarily within a quite separate public administration scholarship, in which the potential for accountability to provide a basis for contesting established norms and power relations has received much less attention.

\section{Implications for the meanings and purposes of accountability}

What then does all of this mean for our understandings of transnational accountability, and our anxieties about whether discourses of accountability are being 'overstretched' or 'overloaded' when extended to the transnational domain? Far from the meaning of accountability becoming lost in its application to analysis of transnational governance, we have observed strong parallels between not only abstract concepts but also concrete practices of accountability at national and transnational levels. In this sense, the analysis presented here has strongly affirmed the conclusion of (KoenigArchibugi 2010) that it would be fruitful for analyses of domestic and transnational accountability to engage more with one another than they currently do, rather than to proceed on separate tracks. 
To the extent that the above analysis has identified distinctive features of accountability in the transnational context, we have seen that these differences can help to illuminate broader dynamics and impacts of accountability within a contemporary governance environment. Most notably, analysis has highlighted how the intrinsically relational or 'external' character of accountability (Mulgan 2000), and thus its foundation on processes of justification to others, gives it a distinctive capacity to challenge established systems in ways that both more routinized or structural checks and balances, or unilateral acts of responsibility, can lack. In practice-particularly in a highly dynamic, complex governance environment- “accountability must constantly be renegotiated among global and local actors” (Weisband and Ebrahim 2007, p.226). The practical implication of this is that accountability can be used not only to protect settled norms and authority relationships from abuse, but also as a vehicle to challenge and reconstruct established normative and institutional relationships.

Whatever institutional form it takes, and whatever relationships and standards it governs, accountability essentially 'works' to the extent that it can secure a sufficient decentralization of effective political agency to provide a basis for enabling political authority to be scrutinised, and where appropriate, effectively contested. The importance of active and dispersed political agency and initiative that must therefore inhere within any functional accountability process establishes a political potential which under certain conditions, particularly visible in many transnational policy fields, can easily be turned away from purposes of scrutinizing deviations from established governance norms, and towards a deeper contestation and transformation of established governance arrangements. This is a lesson that is as relevant for many contexts of contemporary national governance as it is in the transnational domain.

That theories and practices of accountability are as relevant within evolving processes of transnational governance as they are within contemporary practices of public administration and governance-and that important parallels persist between the two — can perhaps also lend weight to (Mulgan 2003, p.ix)'s claim that accountability has attained a status as "one of the core values of democratic governance in the English-speaking world”. Greater engagement between scholars and practitioners grappling with the politics of accountability across these different political domains can surely only enrich our analysis of this complex and yet foundationally important phenomenon.

\section{References}

Benner, T., W. Reinicke, et al. (2004). "Multisectoral Networks in Global Governance: Towards a Pluralistic System of Accountability." Government and Opposition 39(2).

Bovens, M. (2007). "Analysing and Assessing Accountability: A Conceptual Framework." European Law Journal 13(4): 447-468.

Bovens, M. (2010). "Two Concepts of Acountability: Accountability as a Virtue and as a Mechanism." West European Politics 33: 946-967. 
Buchanan, A. and R. O. Keohane (2006). "The legitimacy of global governance institutions." Ethics \& International Affairs 20(4): 405-437.

Chesterman, S. (2008). "Globalization Rules: Accountability, Power and the Prospects for Global Administrative Law." Global Governane 14: 39-52.

Clapp, J. (2005). "Global Environmental Governance for Corporate Responsibility and Accountability." Global Environmental Politics 5(3): 23-34.

Duit, A. and V. Galaz (2008). "Governance and Complexity - Emerging Issues for Governance Theory." Governance: An International Journal of Policy, Administration, and Institutions 21(3): 311-335.

Ebrahim, A. and E. Weisband, Eds. (2007). Global accountabilities: Participation, pluralism and public ethics. Cambridge, Cambridge University Press.

Fox, J. and L. Brown, Eds. (1998). The Struggle for Accountability: The World Bank, NGOs and Grassroots Movements. Cambridge, MIT Press.

Geyer, R. and S. Rihani (2010). Complexity and Public Policy. London, Routledge.

Goodhart, M. (2014). Accountable International Relations. Oxford Handbook of Public Accountability. M. Bovens, R. E. Goodin and T. Schillemans. Oxford, Oxford University Press.

Grant, R. and R. Keohane (2005). "Accountability and Abuses of Power in World Politics." American Political Science Review 99(1).

Harrison, N., Ed. (2006). Complexity in World Politics: Concepts and Methods of a New Paradigm. Albany, SUNY Press.

Held, D. and M. Koenig-Archibugi, Eds. (2005). Global governance and public accountability, Blackwell.

Kahler, M. (2004). "Defining Accountability Up: the Global Economic Multilaterals." Government and Opposition 39(2): 132-158.

Kahler, M. (2009). Networked politics: agency, power, and governance. Ithica, NY, Cornell University Press.

Keck, M. E. and K. Sikkink (1998). Activists beyond borders: advocacy networks in international politics. Ithaca, N.Y., Cornell University Press.

Keck, M. E. and K. Sikkink (1998). Activists beyond borders: Advocacy networks in international politics, Cambridge Univ Press.

Keohane, R. O. (2003). Global Governance and Democratic Accountability. Taming globalization: frontiers of governance. D. Held and M. Koenig-Archibugi. Cambridge, UK, Polity Press: xi, 196.

Kersbergen, K. v. and F. v. Waarden (2004). "Governance'as a bridge between disciplines: Crossdisciplinary inspiration regarding shifts in governance and problems of governability, accountability and legitimacy." European Journal of Political Research 43(2): 143-171.

Kingsbury, B., N. Krisch, et al. (2004). The Emergence of Global Administrative Law. IILJ Working Paper 2004/1. New York, Institute for International Law and Justice, New York University School of Law.

Koenig-Archibugi, M. (2010). "Accountability in transnational relations: how distinctive is it?" West European Politics 33(5): 1142-1164.

Koenig-Archibugi, M. and K. Macdonald (2013). "Accountability-by-proxy in transnational governance." Governance: An international journal of policy, administration, and institutions 26(3): 499-522.

Krisch, N. (2006). "The pluralism of global administrative law." European journal of international law 17(1): 247-278.

Krisch, N. and B. Kingsbury (2006). "Introduction: global governance and global administrative law in the international legal order." European journal of international law 17(1): 1-13.

Macdonald, K. (2007). A Global Agenda for Empowering Southern Workers? Global Accountabilities: Participation, Pluralism and Public Ethics. E. Weisband and A. Ebrahim. Cambridge, Cambridge University Press. 
Macdonald, K. and T. Macdonald (2010). "Democracy in a pluralist global order: Corporate power and stakeholder representation." Ethics \& international affairs 24(1): 19-43.

Mashaw, J. (2005). "Structuring a 'Dense Complexity': Accountability and the Project of Administrative Law." Issues in Legal Scholarship(4).

Mason, M. (2005). The New Accountability: Environmental Responsibility Across Borders. London, Earthscan.

McAdam, D., S. Tarrow, et al. (2001). Dynamics of Contention. Cambridge, Cambridge University Press.

Mulgan, R. (2000). "'Accountability': An Ever-Expanding Concept?" Public Administration 78(3).

Mulgan, R. (2003). Holding Power to Account: Accountability in Modern Democracies. Houndsmill, Palgrave Macmillan.

Newell, P. (2008). "Civil society, corporate accountability and the politics of climate change." Global Environmental Politics 8(3): 122-153.

O'Brien, R., A. M. Goetz, et al. (2000). Contesting global governance: Multilateral economic institutions and global social movements. Cambridge, Cambridge University Press.

Papadopoulos, Y. (2003). "Cooperative forms of governance: Problems of democratic accountability in complex environments." European Journal of Political Research 42: 473-501.

Papadopoulos, Y. (2007). "Problems of democratic accountability in network and multilevel governance." European Law Journal 13(4): 469-486.

Park, S. (2014). "Institutional isomorphism and the Asian Development Bank's accountability mechanism: something old, something new; something borrowed, something blue?" The Pacific Review 27(2): 217-239.

Romzek, B. and M. J. Dubnick (1987). "Accountability in the public sector: Lessons from the Challenger tragedy." Public Administration Review 47(3): 227-238.

Rosenau, J. (1990). Turbulence in World Politics: A Theory of Change and Continuity. Princeton, NJ, Princeton University Press.

Rosenau, J. (2005). Global governance as disaggregated complexity. Contending Perspectives on Global Governance: Coherence, contestation and world order. A. D. Ba and M. J. Hoffmann. London, Routledge.

Rubenstein, J. (2007). "Accountability in an Unequal World." Journal of Politics 69: 616-632.

Scholte, J. A. (2004). "Civil Society and Democratically Accountable Global Governance." Government and Opposition 39(2): 132-158.

Slaughter, A.-M. (2004). "Disaggregated Sovereignty: Towards the Public Accountability of Global Government Networks." Government and Opposition 39(2): 159-190.

Weisband, E. and A. Ebrahim, Eds. (2007). Global Accountabilities: Participation, Pluralism and Public Ethics. Cambridge, Cambridge University Press.

Weisband, E. and A. Ebrahim (2007). Introduction: Forging Global Accountabilities. Global Accountabilities: Participation, Pluralism and Public Ethics. E. Weisband and A. Ebrahim. Cambridge, Cambridge University Press.

Woods, N. (2001). "Making the IMF and the World Bank more accountable." International Affairs 77(1): 83-100.

Zurn, M. (2004). "Global Governance and Legitimacy Problems." Government and Opposition 39(2): 260-287. 


\section{University Library}

\section{- M M I N E R VA A gateway to Melbourne's research publications}

Minerva Access is the Institutional Repository of The University of Melbourne

Author/s:

Macdonald, K

Title:

The Meaning and Purposes of Transnational Accountability

Date:

2014-12-01

Citation:

Macdonald, K. (2014). The Meaning and Purposes of Transnational Accountability. AUSTRALIAN JOURNAL OF PUBLIC ADMINISTRATION, 73 (4), pp.426-436. https:// doi.org/10.1111/1467-8500.12107.

Persistent Link:

http://hdl.handle.net/11343/91824 